\title{
The Importance of Entrepreneurship as a Contributing Factor to Economic Growth and Development:
} The Case of Selected European Countries

\author{
Natanya Meyer, Jacques de Jongh \\ North West University, South Africa \\ Natanya.Meyer@nwu.ac.za, Jacques.deJongh@nwu.ac.za
}

\begin{abstract}
Entrepreneurship has been pointed out as a key contributor to sustained economic growth and development as it not only creates employment, but increased spending in markets, knowledge transfers, employment and innovation. However, very few studies exist that empirically measures the relationship between the three variables; economic growth, economic development and entrepreneurship. Therefore, the purpose of this study is to determine and highlight the importance of entrepreneurship as a contributing factor to economic growth and development. Traditionally, economic growth is measured by the gross domestic product (GDP) of a country. As no formal measurement of economic development exists, an index was created taking into consideration the Human Development Index (HDI), percentage population above the poverty line and employment rate. The entrepreneurship development variable is measured by the Total Early-Stage Entrepreneurial Activity (TEA). The study followed a quantitative research design and made use of secondary time series data with the sample period ranging from 2005 to 2016 . The study area comprised five selected member states of the European Union (EU) which included Germany, the Netherlands, Hungary, Belgium and Poland. Findings suggest that economic growth, development and entrepreneurship seem to be inexplicably connected. As several other factors may also contribute to the fluctuations of economic growth and development results differed from one country to another. However, the analyses from the Dutch, Hungarian and Polish economies for the period under consideration reveal correspondingly healthy economic and social environments where entrepreneurial climates are flourishing. The analysis from Germany and Belgium, however reveal subdued entrepreneurial development. Based on these findings, it is recommended that the development of SME sectors especially in transition economies be centralised as important focus areas towards improving economic and social growth outlooks. In turn, policy stakeholders should ensure the creation of enabling environments structured around responsive micro and macro decision-making.
\end{abstract}

Keywords: Entrepreneurship, economic growth, economic development, European countries

\section{Introduction}

For centuries, entrepreneurship has been identified as a key contributor of employment, innovation and sustained economic growth and development (Acs \& Audretch, 2005; Langevang \& Gough, 2012; Aparicio et al., 2016, Meyer \& Meyer, 2017). However, a renewed emphasis was placed on the role of entrepreneurship and small businesses after the 1980s period of global stagflation and high unemployment levels (Toma et al., 2014). A realisation has emerged that the main contributors to economic growth was no longer predominantly large companies but the small and medium enterprises (SMEs) were making a considerable contribution to the Gross Domestic Product (GDP)of certain economies (Brock \& Evans, 1989; EIM, 1997; Toma et al., 2014). Globally, large industries have been transforming to smaller more robust business models and since the 1970s a considerable amount of literature has emerged making reference to the role and contribution of smaller entrepreneurial businesses in economies (Toma et al., 2014).

The EIM (1997) identified a shift in the composition of the European business environment's contribution to GDP showing that small business growth exceeded that of large businesses for the period of $1988-1997$. Similarly, Brock and Evans, (1989) identified comparable trends in the United States of America. As explained by Wennekers and Thurik (1999), shifts like these could be due to changes in the global economic environment, technological evolutions, supply of labour, increased and improved education levels, consumer preference changes and ease of entry regarding business regulation. The realisation of these global trends has placed much-needed emphasis on the advancement of the small business entrepreneurial sector and its contribution, to not only economic growth, but economic development as well. Therefore, the purpose of this study is to determine and highlight the importance of entrepreneurship as a contributing factor to economic growth and development. The study makes use of a selection of European countries including Hungary, 
Germany, Netherlands, Poland and Belgium to test this relationship and contribution between the three variables; economic growth, economic development and entrepreneurship.

\section{Literature Review}

Several studies have proven that a link between economic growth, development and entrepreneurship exists (Herrington \& Kew, 2013; Naudé, 2013; Meyer \& Meyer, 2017). Herrington and Kew (2013) mention that a consistent correlation between per capita GDP and TEA rates exists and Naudé (2013) found a link between entrepreneurship and economic development. Entrepreneurship is undeniably a large contributor to a country's economic success in terms of its GDP (Tamilmani, 2009; Toma et al., 2014). However, in the modern era, economic growth is not the only aspect to consider when measuring a country's prosperity (Toma et al., 2014). Masoud, (2014) refers to economic growth, from a neo-classical perspective, as a cumulative increase of output, or the accumulation of production factors reflecting a quantitative measurement of a country's progress or growth. To a large extent, the concept of economic growth is based on models mainly developed by traditional economists such as Solow, (1956) Myrdal, (1957) and Rostow, (1959). Economic growth is primarily measured by tracking the progress with regards to a country's GDP and per capita GDP. However, in recent decades, controversies regarding the traditional measurement of GDP to quantity growth were pointed out and one of the main concerns was listed as the exclusion of aspects such as human development, equality and social cohesion (OECD, 2005).

In light of this, Todaro and Smith (2011), refers to the notion of economic development, somewhat in contrast to economic growth (GDP), which encapsulates a multi-dimensional measuring concept specifically including social development aspects and in-turn providing an inclusive impression of a country's progress (Iyer et al., 2005). Notwithstanding this, the traditional measure of growth using the rise and decline in GDP still remains an important economic indicator. The concept of economic development was rarely used in economic literature before the 1930s (Toma et al., 2014). Wennekers and Thurik (1999), refer to this concept as the 'new' endogenous growth theory. As mentioned, the neoclassical growth models such as those of for example Solow, omitted key aspects linked to development and in reaction to this, the endogenous growth theories emerged (Martin \& Sunley, 1998). This theory takes into consideration the impact of endogenous factors as opposed to exogenous factors leading to long-run economic growth. These endogenous factors linking to economic development involves an all-inclusive enhancement of a society's standard of living through the growth of all sectors of the economy, including for example education, health, technology and infrastructure and the overall reduction of poverty and unemployment (Carlson, 1999).

In essence, economic development is the balance between the economic and social dimensions of a country's economy (Huq et al., 2009; Toma et al., 2014). It is important to understand these differences and comprehend that economic growth on its own is not a true reflection of a country's growth and development. As with pure economic growth and development theories, many historical and modern theories, to some degree, touch on the concept of entrepreneurship. However, a few stand out as they encapsulate the essence of entrepreneurship. These include, but are not limited to, Cantillon's theory of entrepren eurship (1755), Von Thünen's location theory (1783 - 1850), Menger's subjective theory of value (1840 - 1921), Marshall's theory of substitution (1842 - 1924), the Schumpeterian theory of innovation (1883 - 1950), Knight's theory of profit (1885 - 1972), Schultz's theory on entrepreneurship (1902 - 1988) and Kirzner's 'alert' entrepreneur (1930 - current) (Bula, 2012). Cantillon (1680-1734), one of the first economists to write about the notion of entrepreneurship, identified an entrepreneur as a risk-taking agent who takes supply and demand into account in order to create balance. He did not view the entrepreneur as a production factor (Bula, 2012).

As part of the original Austrian school, Cantillon (1755), who works was only published two decades after his death, studied entrepreneurship extensively and, at that time, held similar views on entrepreneurship as are currently advanced by the said school of thought. He stated that creating entrepreneurs leads to the development of an economy through the creation of an exchange, price fluctuations, money transfer and increased competition; and added that entrepreneurs are responsible for bringing prices and production in line with demand. Taking the aforementioned into consideration, the Schumpeterian entrepreneurs were perceived as flexible and being creators of variability and creative destruction, thereby referring to the potential creation of new possibilities (Wennekers \& Thurik, 1999; Naudé, 2013). Schumpeter followed a 
different approach to that of Cantillon, mainly by classifying an entrepreneur as an innovator and an agent of change (Toma et al., 2014). His theory assumed that an entrepreneur is an economic and social front-runner and profit is not the main goal of the entrepreneurial activity, but rather that of fulfilling a need in society through new innovations (Bula, 2012).

He proposed that five conditions occur during the entrepreneurial process: new production processes, new products, new markets, new production factors or materials and new ventures (Toma et al., 2014). Conventionally, as theoretical neo-classical models assumed perfect competition and accorded no to little consideration to dynamic innovation in the equilibrium process, there was little room for the concept of entrepreneurship (Wennekers \& Thurik, 1999). Nevertheless, with the founding of the new endogenous growth theory, which had a profound impact on industrial and evolutionary economics and managerial literature, new prospects evolved, opening a door for the development of the concept referred to as entrepreneurship. Wennekers \& Thurik (1999), state that a good example of the insertion of this concept into theory was evident in Romer's model. His model presumed that an instrument of growth can be found in new varieties of capital goods. In addition, Romer's model proposes that growth can be driven by the development of new products; thus economic change could be sparked by the various activities executed by profitpursuing entrepreneurs.

When considering the link between entrepreneurial activity and economic growth, two key roles of an entrepreneur are identified. The first refers to new entry, which denotes the role of creating a new business, regardless of the level of innovation. The second refers to innovation or novelty as a key economic role which ultimately entails transforming ideas and discoveries into economically feasible actions (Baumol, 1993; Toma et al., 2014). This 'newness' achieved by means of ground-breaking innovation may be considered one of the most relevant factors linking entrepreneurship to economic growth and development (Toma et al., 2014). The very existence of entrepreneurship is key to economic functioning as it addresses inadequacies within economies and directly contributes to market supply and demand. As stated, entrepreneurship is directly and indirectly linked to economic growth and development (Wennekers \& Thurik, 1999; Herrington \& Kew, 2013; Meyer \& Meyer, 2017). Several studies have empirically proven this link. For example, Toma et al. (2014) identified entrepreneurship as a booster of economic growth, occurring for a number of reasons, including improved competition as the number of businesses increases, knowledge 'spill-over' and diversity and innovation created amongst economic agents. The first of these, improved competition as the number of businesses increases, directly contributes to growth since an increase in the number of businesses eventually leads to an increase in employment. Moreover, competition creates a conducive environment for the growth of knowledge which leads to the second economic booster.

Knowledge 'spill-over' are created as new knowledge is created the effects thereof are transferred to other individuals or businesses. Knowledge 'spill-over' is an important causal instrument for endogenous growth. The third reason refers to the diversity and innovation that is created by economic agents which creates uniqueness and in turn influences economic growth. Audretsch and Thurik, (2000) found further empirical evidence in a longitudinal study conducted amongst 23 OECD countries over a period of 20 years (19741994). The study specifically focussed on the effect the number of entrepreneurs had on unemployment levels. Results indicated that the number of small businesses had a positive correlation to employment levels, thus more small businesses resulted in lower levels of unemployment. Meyer and Meyer (2017), conducted a pooled panel time-series analysis annual secondary data from2001 to 2015 for the BRICS countries. Results indicated that-long run relationship existed between the dependent variables of GDP and employment and the independent variables which included TEA, entrepreneurial intention (EI) and established business ownership rates (EBO). In addition, further results indicated that TEA and EI are significant predictors of economic growth (GDP), and that established business ownership is a significant predictor of employment.

The traditional measures of growth and development were explained earlier, however entrepreneurship is not such an easy concept to measure (Wennekers \& Thurik, 1999). Nonetheless, over the past 19 years, the GEM Consortium has developed a method to measure and compare cross-national entrepreneurial activity as well as perform intra-country time series analysis. In order to provide data that can be used for reliable comparisons the GEM makes use of a standardised research design for all countries. The most well-known and used indicator to measure entrepreneurship is the Early-stage entrepreneurial activity (TEA) which 
consists of two stages: nascent and new entrepreneurs. TEA can be defined as the percentage of the adult population between the ages of 18 and 64 years who have very recently started a business or who are in the process of doing so (Herrington \& Kew, 2013). Nascent entrepreneurs are defined as people who have started a new business but who have either not paid salaries to employees or if salaries have been paid, they were for less than three months (Herrington et al., 2015). Entrepreneurial activity is represented by the total earlystage entrepreneurial activity (TEA) index.

New business ownership rates include those who have paid salaries to employees for more than three consecutive months, but whose businesses are not older than 42 months, as semi-established businesses (Herrington et al., 2015). The GEM considers TEA to be the most important entrepreneurial indicator as this is potentially the group of businesses that might successfully grow into established ones. TEA levels could fluctuate with levels of unemployment and, in some cases, be higher when unemployment is high due to job demands not being met by the private and public sector (Herrington \& Kew, 2013). In conclusion, entrepreneurship does impact economic growth and development positively for a number of reasons as listed in the aforementioned discussion and as entrepreneurship development is equally important for economic growth and economic development, a deeper understanding of this topic is fundamental to the existing body of knowledge.

\section{Methodology}

This section elaborates on the methodology that was used during the research process. The research purpose study areas as well as the data and sample period that was used are discussed. Furthermore, a clear and concise discussion of the techniques that were used during the analysis is provided.

Data, Variables and Sample Period: The study made use of time series data with the sample period ranging from 2005 to 2016. This time period was chosen based on the availability of data. A total of three variables were selected for the analysis. These included the annual percentage growth in the gross domestic product (GDP) per capita and a self-constructed composite economic development index ranging from 0 to 100 . The index was constructed by Meyer et al. (2016) and was simplified for this study using three indicators including the HDI, the percentage of the population at risk of poverty and social exclusion and finally, the unemployment rate (all equally weighted). The index was constructed by using three indicators including the HDI as a measure of human development, the percentage of the population at risk of poverty and social exclusion and finally, the unemployment rate (all equally weighted). All three indicators were converted to ensure the analytical soundness of the index. This indicator represents the percentage of population between 18 to 64 years old who are either nascent entrepreneurs or owners of a business which is less than 42 months old (Herington et al., 2017). However, for the purpose of the study this variable was converted to indicate the number of people of the population not involved in the early-stage entrepreneurial activity. All selected variables together with the conversions and interpretations are shown in Table 1.

Table 1: Variable Identification and Interpretation

\begin{tabular}{|c|c|c|c|}
\hline Indicator & Variables & Conversion & Interpretation \\
\hline $\begin{array}{l}\text { Gross domestic } \\
\text { product (GDP) } \\
\text { growth }\end{array}$ & $\begin{array}{l}\text { GDP per capita } \\
\text { growth (annual \% } \\
\text { change) }\end{array}$ & $\begin{array}{l}\text { Measured with a base score of } \\
90 .\end{array}$ & $\begin{array}{l}\text { GDP growth rate with a base of } 90 . \\
\text { Score higher than } 90 \text { indicates } \\
\text { positive growth, where scores } \\
\text { lower than } 90 \text { indicates negative } \\
\text { growth. }\end{array}$ \\
\hline $\begin{array}{l}\text { Economic } \\
\text { development } \\
\text { index }\end{array}$ & $\begin{array}{l}\text { HDI, the } \\
\text { percentage of the } \\
\text { population at risk } \\
\text { of poverty and } \\
\text { social exclusion, } \\
\text { unemployment } \\
\text { rate. }\end{array}$ & $\begin{array}{l}\text { HDI expressed as percentage } \\
\text { (HDI x } 100) ; \% \text { of the population } \\
\text { not at risk of poverty and social } \\
\text { exclusion }(100-\% \text { of the } \\
\text { population at risk of poverty and } \\
\text { social exclusion; } \\
\text { Employment rate ( } 100 \text { - } \\
\text { unemployment rate). Three } \\
\text { variables used to construct index }\end{array}$ & $\begin{array}{l}\text { The index score is ranging from } 0 \\
\text { to } 100 \text {. Higher scores indicate } \\
\text { higher levels of economic } \\
\text { development. }\end{array}$ \\
\hline
\end{tabular}


equally weighted.

Negative TEA (NTEA),

Total Early Stage

NTEA entrepreneurial

activity (TEA)
(100 - TEA rate). Includes the number of people not involved in the early-stage entrepreneurial activity (TEA)
Indicates the $\%$ of the population not involved in any early-stage entrepreneurial activities. The score ranges from 0 - 100 with lower scores indicating higher involvement.

Source: Authors' own compilation

Research Purpose and Design: The study comprised both a qualitative and quantitative research approach. The qualitative part included an extensive literature review that was based on key concepts of economic growth, entrepreneurship and economic development. More specifically, the inquiry focused on the link between entrepreneurial activity and its respective contribution towards stimulating economic activity and alleviating poverty and unemployment. The quantitative aspects involved the use of secondary data that was acquired through the use of various sources. These included the World Bank and Euro stat while all entrepreneurial data were obtained from the Global Entrepreneurship Monitor Consortium.

The Study Area: The chosen study area comprised of five selected member states of the European Union (EU) which included Germany, the Netherlands, Hungary, Belgium and Poland. Entrepreneurial activity within these countries and in the EU region in general is seen as an important driver for employment growth together with strong linkages to economic dynamism and innovation (Rusu \& Roman, 2017). These attributes together with the unique intricacies of being governed by common standards, yet faced by ever increasing global and diversified markets prompted the choice of the study area. Furthermore, the inherent differences between more advanced European economies (Germany, Netherlands, Belgium) and their transitional (Hungary and Poland) counterparts serve as an interesting framework towards the analysis of the impact of entrepreneurship on the socio-economic environment in Europe.

Data Analysis: Data for selected variables were analysed through the use of a descriptive analysis technique. This involved the examination of the underlining economic, social and entrepreneurial climates for each of the selected countries between 2005 and 2016. Time trends for each of the countries are shown in Figures 1 to 5 with the purpose of ascertaining the relationship between entrepreneurship, economic growth and development.

\section{Results and Discussion}

This section reports the results of the study. More specifically, the trends of the selected European countries pertaining their entrepreneurial climate, economic development and subsequent growth performances are evaluated and discussed for the period ranging from 2005 to 2016.

Hungary: Classified as a transition economy in the central European region, the Hungarian economy has experienced significant changes over the last few decades (WEF, 2017). The country has been earmarked by large-scale transitions from a centrally planned system to a pure market system which has had a profound impact on the economy's performance (Bozóki, 2008). This transition together with its subsequent reduction of public sector involvement, the emergence of private ownership and large-scale Foreign Direct Investment (FDI) in the modern economy saw the countries acceptance to the European Union in 2004 bringing with it large-scale development. Results from Figure 1 indicate some of these changes where the Hungarian economy, in the past 12 years, has shown significant improvements especially in their entrepreneurial climate. Results show that NTEA rates since 2005 have dropped from 98.12 percent to 92.06 in 2016, indicating an increase in a number of people involved in starting a business. This has been accompanied by significant increases in other related entrepreneurial indicators, where Entrepreneurial Intention (EI) has improved by 13.56 percent to an estimated 15.11 percent in 2016 whilst, Established Business Ownership (EBO) rates have increased from 2.05 percent in 2005 to 5.50 percent in 2016 (GEM Consortium, 2018a).

The increase in entrepreneurial activity as shown in Figure 1 can primarily be asserted to the vast expansion of the small business sector and enterprises in the Hungarian economy (Szira, 2014). According to the OECD 
(2016a), this expansion has brought with it the creation of privatised local markets, subcontracting of largescale state-owned enterprises and additional job creation opportunities that have spurred labour market growth. Furthermore, the increase in entrepreneurial activity contributed to improved competitiveness especially for export sectors as well as resource mobility and increased risk-taking abilities which has in-turn had positive consequences for underlining economic development and growth (Dudin et al., 2016). As seen from Figure 1, economic development index scores improved from 80.06 to 84.06 for the period under review. However, noticeable fluctuations in economic growth and reductions in economic development levels between 2008 and 2013 (Figure 1) show the strong impact the global financial crisis had on economic activity. This is particularly evident in GDP growth rates between 2008 and 2009 where the Hungarian economy contracted by an estimated 6.6 percent.

\section{Figure 1: Hungarian NTEA Rates, Economic Development Scores and GDP Per Capita Growth Rates}

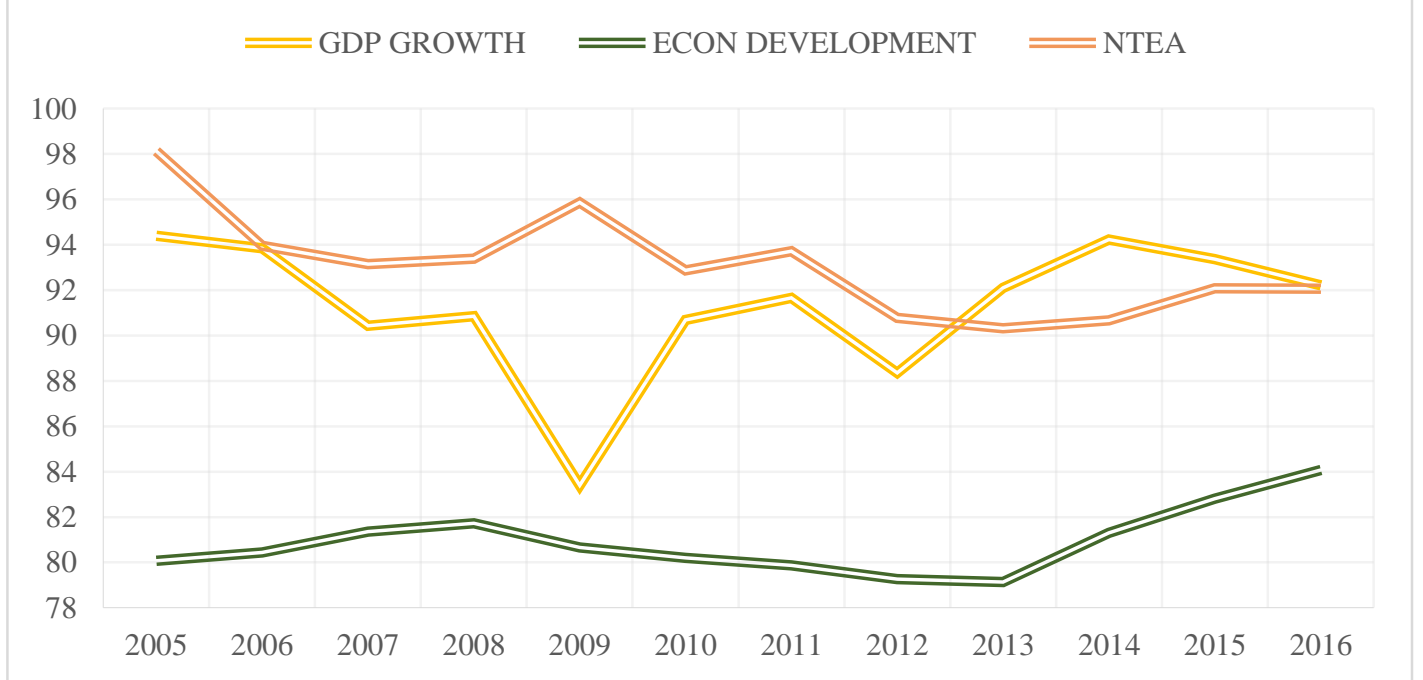

Source: GEM Consortium, 2018b; Euro stat, 2018; World Bank, 2018

Germany: Figure 2 shows Germany's performance for the selected indicators from 2005 to 2016. From this figure it can be observed that amongst the selected countries included in this study, Germany has shown little improvement in their entrepreneurial climate. In fact, the country boasts the highest NTEA rate (lowest involvement in entrepreneurial activity), estimated at 95.44 percent. Additionally, lower intention rates (6.23\% in 2016) are also recorded when compared to the global average (22.32\%) (GEM Consortium, 2018c). Holicza and Tokody, (2016) note that the crisis had a detrimental impact on the country's SME sector to which it increased fear of failure rates from 17 percent before 2008 to more than 42 percent in 2014 . Together with growing small business bankruptcies, lack of investment, as well as significant job losses, the lower rates shown are indicative of the lack of a strong entrepreneurial climate in the country. However, despite this low entrepreneurial involvement in economic processes the country has maintained stable economic growth levels over the past decade which has far surpassed other countries (Folkerts-Landau, 2016). Similar to the experiences of Hungary, economic activity did show significant sensitivity to the onset of the global financial crisis (Funk, 2012) where growth rates contracted by 5.62 percent between 2008 and 2009. Nevertheless, the country showed strong and rapid economic recovery which since has carried over to recent strong performances. Bastasin (2016) notes that these continued performances have been the main result of stable fiscal and monetary positions, low household and consumer debt levels as well as advanced infrastructural developments rather than entrepreneurial prosperity in the economy. 
Figure 2: German NTEA Rates, Economic Development Scores and GDP per Capita Growth Rates

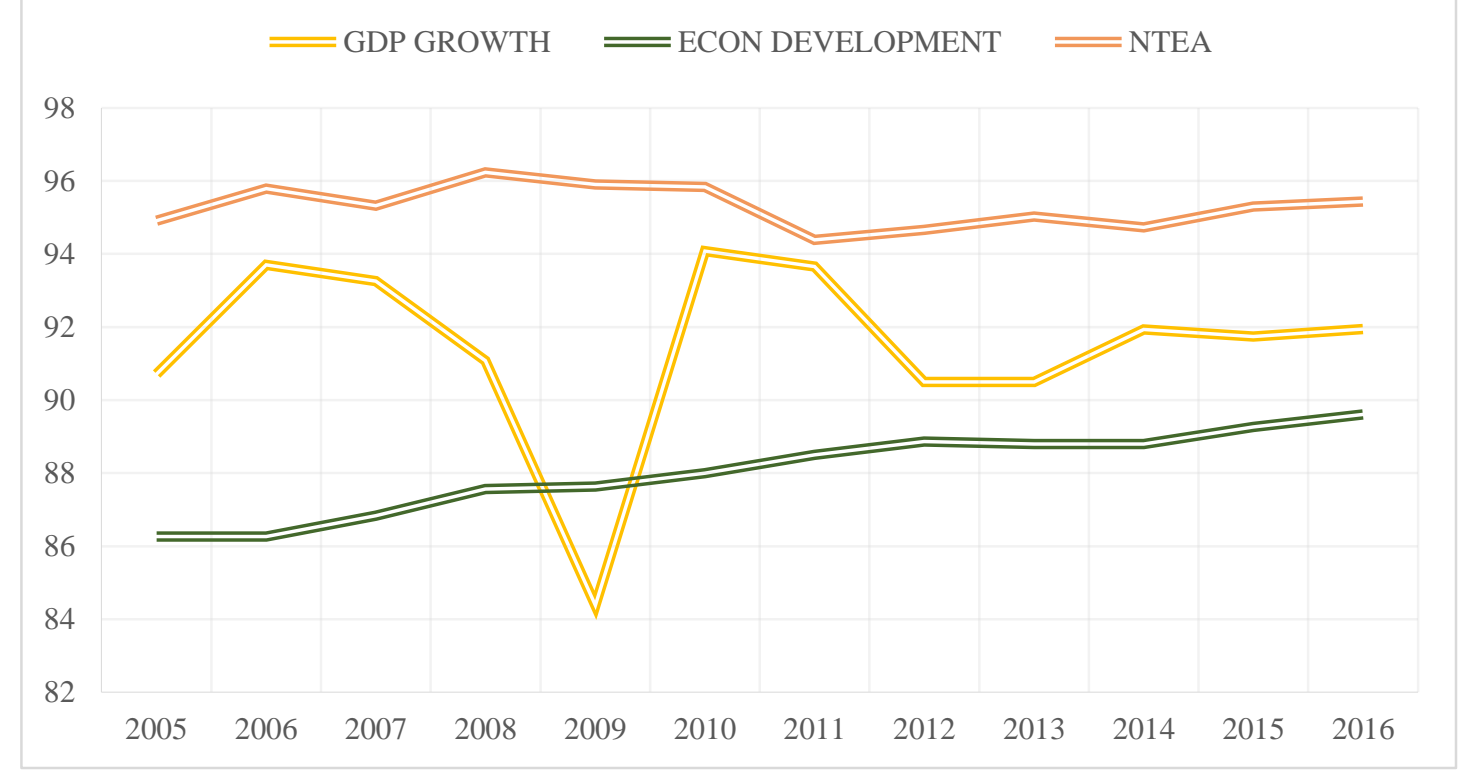

Source: GEM Consortium, 2018b; Euro stat, 2018; World Bank, 2018

In relation to the stable growth prospects attained by Germany, it can be observed from Figure 2 that economic development levels have similarly shown consistent improvement over the 12-year period. Development index scores show continuous increments ranging from 86.26 (2005) to 89.60 (2016) even despite recorded growth fluctuations in 2009. These findings suggest a minimal contribution of the inherent German entrepreneurial climate towards economic growth and development. Low entrepreneurial involvement in this regard can be ascribed to efficient labour markets attributing significantly low unemployment levels (GEM Consortium, 2018c). This is further compounded by cognisance of a lack of entrepreneurial culture and lower perceptions of entrepreneurship as a viable career choice in the country (Raible, 2016). Economic growth and development in this regard are rather driven by stable long-term technological based manufacturing and political stability which have significantly contributed to high employment levels, inclusivity and a virtuous quality of life (Folkerts-Landau, 2016).

Netherlands: The third country under consideration included the Netherlands. Economic development index scores, growth rates and NTEA rates for the country are shown in Figure 3. As observed, the Netherlands boasts the highest recent economic development scores (89.9) amongst the selected countries. Additionally, the lowest NTEA rates (89.0\%) for 2016 are recorded. For the period under review, the Netherlands have reduced NTEA rates from the high 95.44 percent to below 90 percent. This suggests a significant increase in the number of people involved in entrepreneurial activities since 2005. Empirical finding in similar studies (Stam, 2015) show that entrepreneurship has played a pivotal role in the country's economic performance. In this regard the OECD (2016b) note that entrepreneurship has significantly contributed to improved trade and the development of one of the leading global export bases. Furthermore, these processes have assisted in increased industry diversification, local and national competitiveness as well as sustained job creation over the 12-year period (OECD, 2016b). These effects are particularly evident in Figure 3. Economic growth rates in the Dutch economy shows various fluctuations, taking into account the financial crisis of 2008. However, recovery since these timeframes show positive upward trends especially from 2012 onwards (ranging from $1.06 \%$ to $2.2 \%$ in 2016). Goldhausen (2017) indicates that one of the underlining drivers of the recovery has been the SME sector performance and its contribution towards fostering innovation and reducing unemployment levels. 
Figure 3: Netherlands NTEA Rates, Economic Development Scores and GDP Per Capita Growth Rates

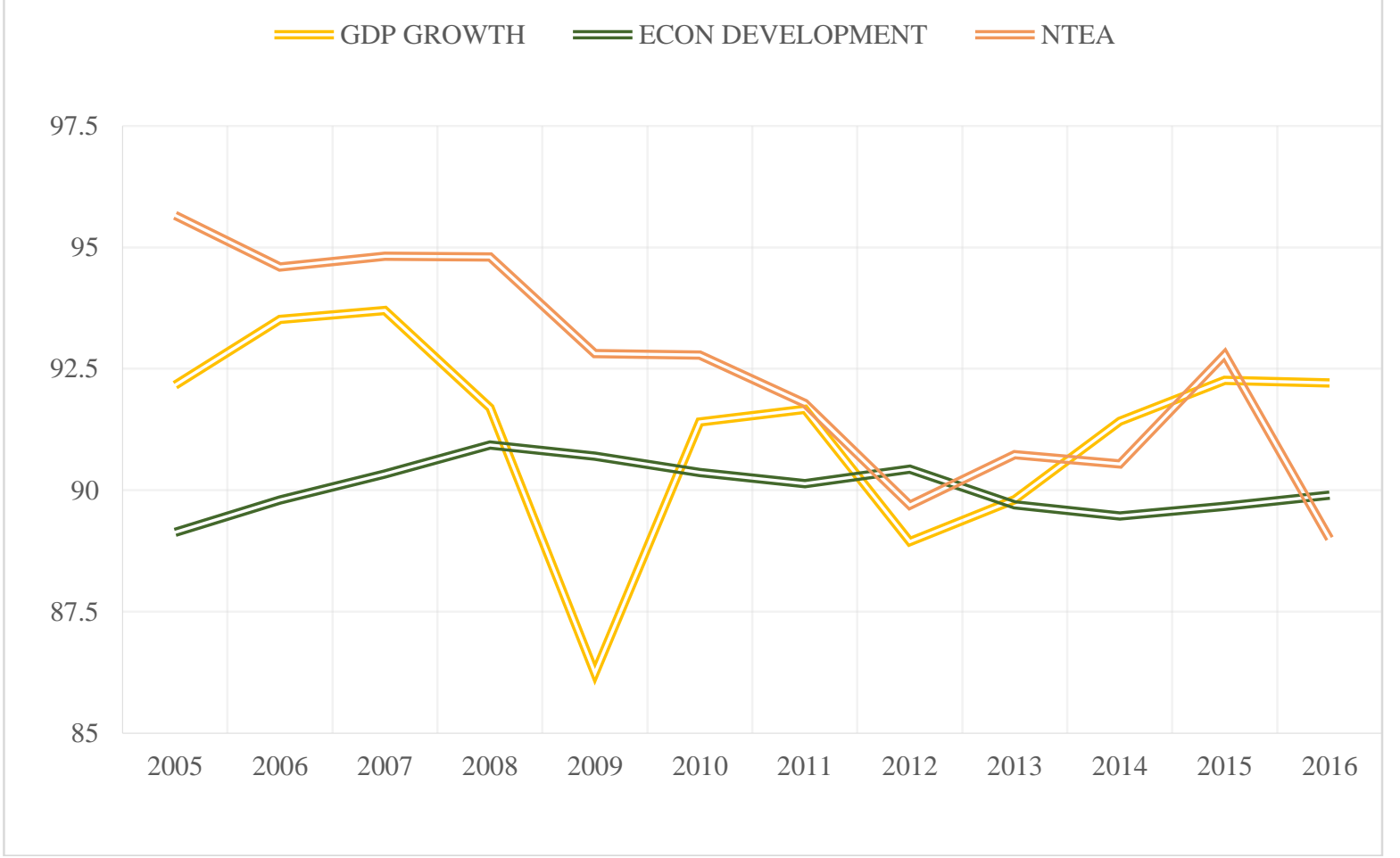

Source: GEM Consortium, 2018b; Euro stat, 2018; World Bank, 2018

Whilst these trends show a suggestable strong relationship between Dutch economic growth and entrepreneurship, the importance of the improving entrepreneurial climate towards economic development cannot be ignored. As observed from Figure 3, pre-crisis (2005 - 2008) and post-crisis (2010 - 2016) trends for the NTEA and economic development index show simultaneous reductions and increments, illustrating the positive relationship between venture creation and its subsequent impact on economic development. However, as observed during the crisis, lower employment rates and higher poverty risks tend to induce a movement towards increased entrepreneurial involvement (lower NTEA rates). Wennekers et al. (2010) likewise suggest a bidirectional relationship between economic development and entrepreneurship. In this regard innovation-driven venture creation can contribute to improved standards of living and knowledge transfers, while lower economic development (higher unemployment and poverty) induces a greater involvement in entrepreneurial activities primarily due to the lack of employment opportunities and lower income levels (Mojica-Howell et al., 2012).

Poland: As part of the countries that are included in the efficiency classification, results from Figure 4 shows that Poland attributed amongst the most stable conditions in the past 12-years. NTEA rates for the period ranging from 2005 to 2016 maintained a consistent level close to 91 percent with slight reductions from 2015 to 2016. These rates together with a high intention to start a business rate (20.66) as well as comparatively (other efficiency-driven economies) high established business ownership rates (7.1\%) attribute a sound and healthy entrepreneurial climate in the economy (GEM Consortium, 2018d). This has likely contributed to similar stable trends shown in GDP per capita growth rates as shown in Figure 4. Although having noticeable declines in 2008 and 2009, the Polish economy has maintained positive growth rates. During the global crisis the economy was the sole EU state member who avoided the economic recession (Orłowski, 2011). Paulina (2017) points the continued strong and stable performance to among others, are pensive macroeconomic policy, a large domestic economy and finally the sustained confidence of local entrepreneurs which brought with it diversified export structures and significant fund inflows. 


\section{Figure 4: Polish NTEA Rates, Economic Development Scores and GDP Per Capita Growth Rates}

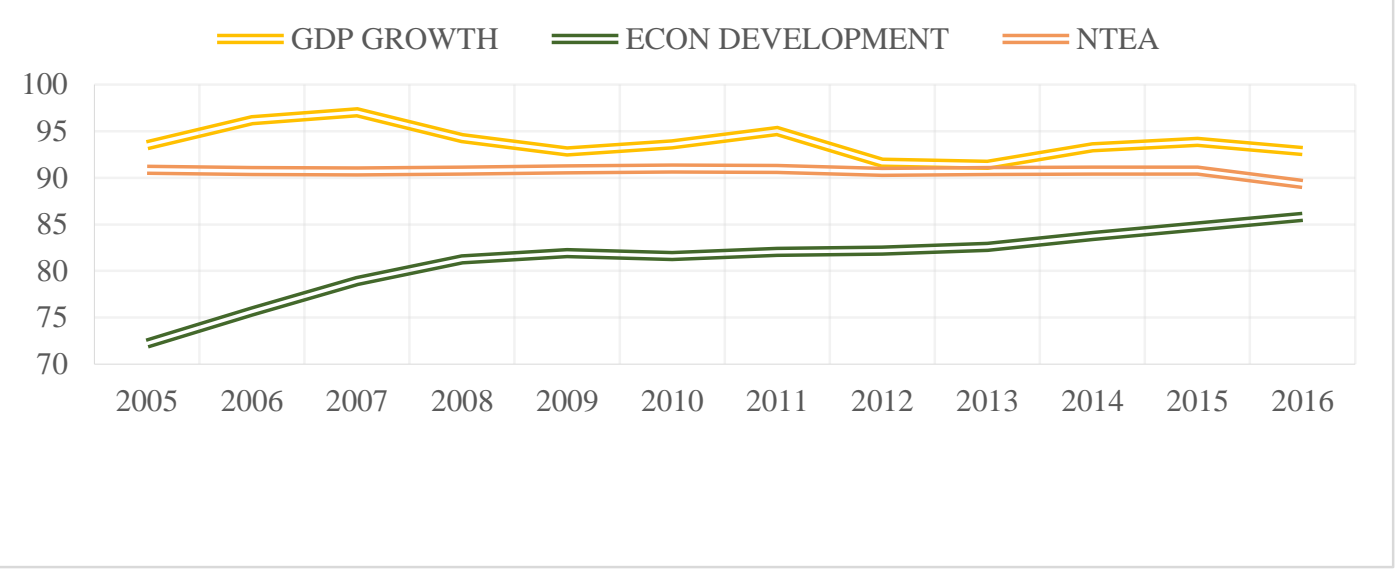

Source: GEM Consortium, 2018b; Euro stat, 2018; World Bank, 2018

In light of the stable entrepreneurial and economic conditions shown over the last two decades, Poland's economic development levels have shown significant improvement. Trends shown in Figure 4 indicate an increase of 13.6 index points in the last 12 years moving from 72.2 in 2005 to 85.8 in 2016. Sienkiewicz (2014) showed that business formation and the fostering of an effective and enabling entrepreneurial climate had contributed significantly towards Polish employment levels as well as the development of infrastructural capacities. These have concomitantly been supplemented by a growing diversified product line, innovation creation processes, job security, improved productivity, enhanced regional competitiveness and the creation of better intellectual capital (Paulina, 2017). The significance of these findings suggests that stable economic as well entrepreneurial conditions prove pivotal for enhanced economic development levels. In this regard, the provision of economic conditions which is centralised around localised strategies and policy responsiveness assures business confidence and venture creation (Sienkiewicz, 2014). These in turn, provide a labour market supplemented by small and medium enterprise led growth contributing to the reduction of unemployment levels, fostering an improved standard of living and establishing a diversified economic structure (Mularska-Kucharek \& Wiktorowicz, 2015).

Belgium: Belgium constituted the final country pertaining, the analysis of the three selected variables for the study. Results for the country concerning entrepreneurship, economic growth and development are shown in Figure 5. As observed from the figure, NTEA rates for the period under consideration show reductions from 96.07 percent (2005) to 94.82 percent (2016). However, amongst the selected countries, NTEA rates are the second highest only trailing Germany. Other indicators, such as the EBO rate (3.75\%), EI rate (10.85\%) and Motivational Index rate (1.61\%) are also well below regional and developmental level averages all suggesting a low entrepreneurial climate in the country (GEM Consortium, 2018e). Interestingly, economic development index scores only show subdued improvement over the 12-year period. Recent index scores (86.93 in 2016) are the lowest amongst the included developed and innovation-driven economies in the study (shown in Figure 5). In this regard, lower entrepreneurial involvement possibly can contribute to the lower development levels in the Belgium economy. Dumont and Kegels, (2016) in their findings illustrate the country's lack of young firm creation, highlighting its subsequent effect in lowering productivity, technical efficiency and innovative activities that prove crucial towards fostering higher development. 
Figure 5. Belgian NTEA Rates, Economic Development Scores and GDP Per Capita Growth Rates

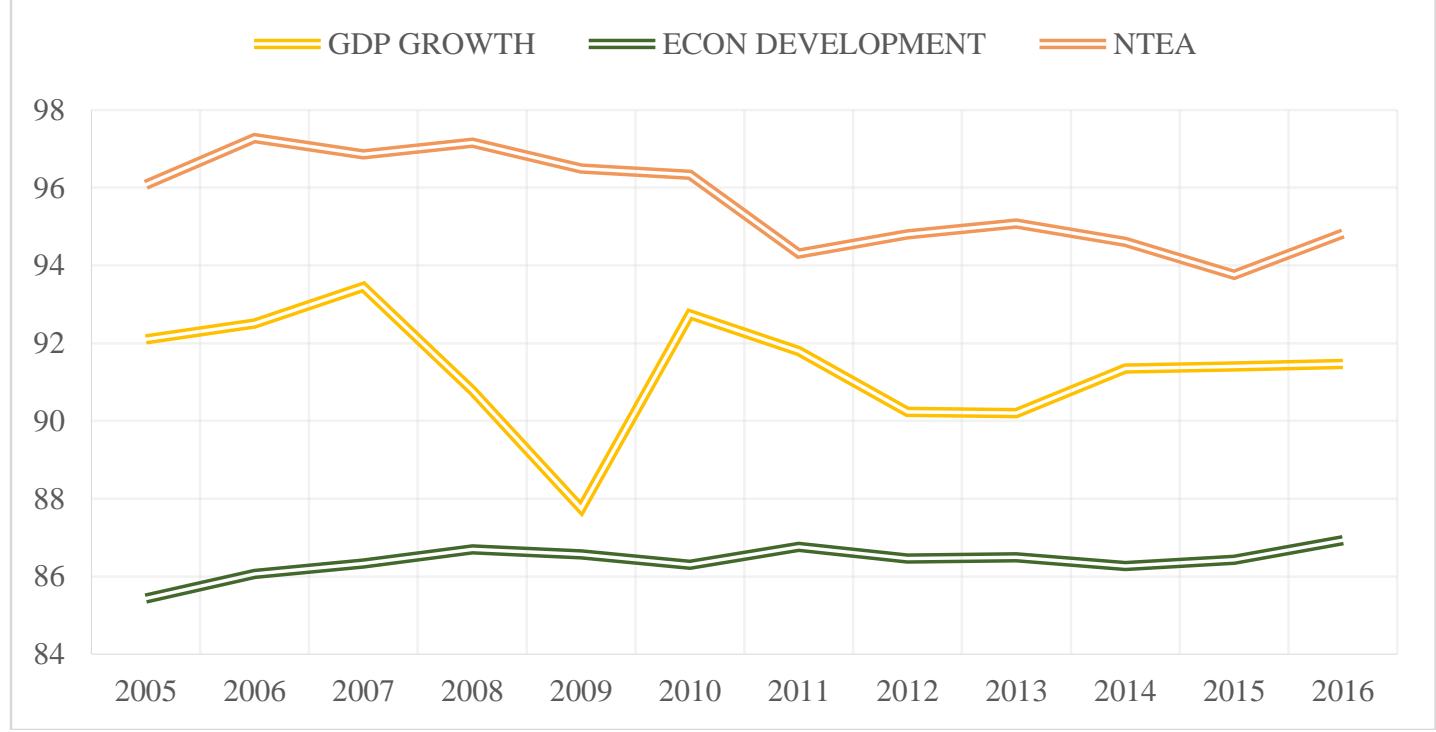

Source: GEM Consortium, 2018b; Euro stat, 2018; World Bank, 2018

Based on the results from Figure 5, the relationship between entrepreneurship and growth in GDP per capita tend to correspond with the findings of the recent GEM report (Holvoet et al., 2015) for the country. According to the report, entrepreneurs in the Belgium economy were more inclined to be necessity-driven rather than opportunity-driven (Holvoet et al., 2015). This is illustrated in lower growth rates between 2007 and 2009 and 2010 and 2013 with concomitant lower NTEA rates for these periods (shown in Figure 5). Whilst these trends are unique, especially for the innovation-driven economies, it signals possible barriers restricting the potential contribution of entrepreneurship to current mediocre growth and development levels. In this regard, and in providing an enabling environment for the entrepreneurial activities, recent GEM rankings for the country illustrate strong performances in the provision of physical as well as commercial and legal infrastructure (GEM Consortium, 2018e). However, the country ranks poorly with regards to education at school, government support and illustrates weak perceptions of entrepreneurship as a viable career choice. From this point of view, it is clear that both social and public sector support proves pivotal in spurring on entrepreneurial involvement and increasing its impact on the economic and social performance of not only transitional economies but more developed nations as well.

\section{Implications and Recommendations}

The results from the study disclose various implications. Upon reflection, economic growth, development and entrepreneurship seem to be inexplicably connected. Whilst the causality of these relationships are unclear from this specific study, the analyses from the Dutch, Hungarian and Polish economies for the period under consideration reveal correspondingly healthy economic and social environments where entrepreneurial climates are flourishing. As shown in the empirical evidence this tends to resonate around the ability of entrepreneurs to instil additional added innovation, knowledge transfers and diversification processes in economic structures. The analysis from Germany and Belgium however, reveal subdued entrepreneurial development. Results suggest that the provision of sound infrastructural capacity and regulatory frameworks are not sufficient in cultivating and taking advantage of the intrinsic potential that entrepreneurship provides. Rather support should include strong policy backing, localised strategies and cultivating societal and educational views on the viability and significance of self-employment and venture creation. This furthermore highlighted the bidirectional significance between entrepreneurship and stable economic conditions amongst the selected countries. Based on these findings, it is recommended that the development of SME sectors especially in transition economies be centralised as important focus areas towards improving economic and social growth outlooks. In turn, policy stakeholders should ensure the creation of enabling environments structured around responsive micro and macro decision making. This should include the removal of business stumbling blocks whilst additionally providing the adequate training initiatives that instil 
business confidence. Lastly, governments should prioritise the emphasis on entrepreneurship development as early as primary school levels with the focus on improving social and cultural norms regarding selfemployment and venture creation.

Conclusion: The results of the study highlighted several important aspects. Amongst these, findings showed noticeable linkages between entrepreneurial activity and the selected countries' economic performances. Entrepreneurship seems to play a key role in establishing diversified economic structures, innovation creation processes, whilst serving as crucial buffers to economic shocks within the EU. Results pertaining to growth and development suggest these indicators be significantly intertwined with the provision of enabling environments together with the strong public sector and social support proving pivotal for entrepreneurship development. Nevertheless, the unique intricacies of each country seem to affect and alter these relationships. Limitations of the study were primarily based on the descriptive nature of the analysis. The lack of long time series data in this regard prevented the use of any causal, predictive or confirmatory statistical methods in the study. This does however provide room for future research endeavours. Studies directed towards the particular area of interest may look to the use of panel data methodologies or other intercontinental comparisons in order to ascertain a more definitive conceptualisation on the relationship between entrepreneurship, development and economic growth amongst these countries.

\section{References}

Acs, Z. J. \& Audretsch, D. B. (2005). Entrepreneurship and innovation (No. 2105). Papers on Entrepreneurship, Growth and Public Policy.

Aparicio, S., Urbano, D. \& Audretsch, D. (2016). Institutional factors, opportunity entrepreneurship and economic growth: Panel data evidence. Technological Forecasting and Social Change, 102(1), 45-61.

Audretsch, D. B. A. \& Thurik, A. R. (2000). Capitalism and democracy in the 21st century: From the managed to the entrepreneurial economy. Journal of Evolutionary Economics, 10(2000), 17-34.

Bastasin, C. (2016). Germany: a global miracle and a European challenge. Global Economy \& Development Working Paper No. 62, Brookings, Washington, D.C.

Baumol, W. J. (1993). Formal entrepreneurship theory in economics: Existence and bounds. Journal of Business Venturing, 8, 197-210.

Bozóki, A. (2008). Consolidation or second revolution? The emergence of the new right in Hungary. Journal of Communist Studies and Transition Politics, 24(2), 191-231.

Brock, W. A. \& Evans, D. S. (1989). Small business economics. Small Business Economics, 1, 7-20.

Bula, H. O. (2012). Evolution and theories of entrepreneurship: A critical review of the Kenyan perspective. International Journal of Business and Commerce, 1(11), 81-96.

Cantillon, R. (1755). Essai Sur La Nature Du Commerce in Général (Essay on the Nature of Trade in General) London: Frank Cass and Co., Ltd. Translated and republished in 1959.

Carlson, B. A. (1999). Social dimensions of economic development and productivity: Inequality and social performance. An overview. (In B.A. Carlson, eds. Social dimensions of economic development and Productivity: Inequality and social performance. Santiago: United Nations. p. 7-19).

Dudin, M. N., Voykova, N. A., Galkina, M. V. \& Vernikov, V. A. (2016). Development of Hungary's Manufacturing Industry in the Conditions of European Integration. International Journal of Economics and Financial Issues, 6(5), 48-52.

Dumont, M. \& Kegels, C. (2016). Young Firms and Industry Dynamics in Belgium. Federal Planning Bureau Working Paper No. 6-16. Federal Planning Bureau, Brussels.

EIM. (1997). The European Observatory for SMEs. $5^{\text {th }}$ Annual report, Zoetermeer.

Euro stat. (2018). People at risk of poverty and social exclusion. [Online], Euro stat.

Folkerts-Landau, D. (2016). Beacon of stability: The foundations of Germany's success. Deutsche Bank Research, Frankfurt.

Funk, L. (2012). The German Economy During the Financial and Economic Crisis Since 2008/2009: An Unexpected Success Story Revisited. Konrad Adenauer Stiftung, Berlin.

GEM Consortium. (2018a). Entrepreneurial behaviour and attitudes: Hungary [Online]. Global Entrepreneurship Research Association.

GEM Consortium. (2018b). Entrepreneurial behaviour and attitudes. [Online], Global Entrepreneurship Research Association. 
GEM Consortium. (2018c). Entrepreneurial behaviour and attitudes: Germany. [Online], Global Entrepreneurship Research Association.

GEM Consortium. (2018d). Entrepreneurial behaviour and attitudes: Poland. [Online], Global Entrepreneurship Research Association.

GEM Consortium. (2018e). Entrepreneurial behaviour and attitudes: Belgium. [Online], Global Entrepreneurship Research Association.

Goldhausen, J. (2017). Access to finance and growth: Evidence from Dutch SMEs. [Online]. University of Twente.

Herrington, M. \& Kew, J. (2013). GEM 2013 South African Report: Twenty Years of Democracy. University of Cape Town Centre for Innovation and Entrepreneurship. Cape Town, South Africa.

Herrington, M., Kew, J. \& Kew, P. (2015). 2014 GEM South Africa report: South Africa: The crossroads - a goldmine or a time bomb? University of Cape Town Centre for Innovation and Entrepreneurship. Cape Town, South Africa.

Herrington, M., Kew. P. \& Mwanga, A. (2017). South Africa Report: Can Small Businesses Survive in South Africa, University of Cape Town Centre for Innovation and Entrepreneurship, Cape Town: South Africa.

Holicza, P. \& Tokody, D. (2016). Field of challenges: A critical analysis of the Hungarian SME sector within the European economy. Hadmérnök, 9(3), 110-120.

Holvoet, T., Bosma, N. \& Crinjs, H. (2015). Global Entrepreneurship Monitor Report for Belgium and Flanders, Global Entrepreneurship Research Association, London.

Huq, M. M., Clunies-Ross, A. \& Forsyth, D. (2009). Development Economics. London: McGraw Hill Education.

Iyer, S., Kitson, M. \& Toh, B. (2005). Social capital, economic growth and regional development. Regional Studies, 39(8), 1015-1040.

Langevang, T. \& Gough, K. V. (2012). Diverging pathways: Young female employment and entrepreneurship in Sub-Saharan Africa. The Geographical Journal, 178(3), 242-252.

Martin, R. \& Sunley, P. (1998). Slow convergence? The new endogenous growth theory and regional development. Economic geography, 74(3), 201-227.

Masoud, N. (2014). A contribution to the theory of economic growth: Old and new. Journal of Economics and International Finance, 6(3), 47-61.

Meyer, D. F., De Jongh, J. J. \& Meyer, N. (2016). The formulation of a composite regional development index. International Journal of Business and Management Studies, 8(1), 100 - 116.

Meyer, N. \& Meyer, D. F. (2017). An econometric analysis of entrepreneurial activity, economic growth and employment: The case of the BRICS Countries. International Journal of Economic Perspectives, 11(2), 429-441.

Mojica-Howell, M. N., Whittaker, W. L., Gebremedhin, T. G. \& Schaeffer, P. V. (2012). Examining The Bidirectional Relationship Between Entrepreneurship and Economic Growth: Is Entrepreneurship Endogenous. Entrepreneurship-Born, Made and Educated, Burger-Helmchen, T. (ed), In Tech, London.

Mularska-Kucharek, M. \& Wiktorowicz, J. (2015). Entrepreneurship of rural residents in Poland. Acta Scientiarum Polonorum. Oeconomia, 14 (3), 83-93.

Myrdal, G. (1957). Rich Lands and Poor. New York: Harper and Row.

Naudé, W. A. (2013). Entrepreneurship and Economic Development: Theory, Evidence and Policy. Discussion Paper, IZA DP No. 7507. Maastricht: University of Maastricht.

OECD (Organisation for Economic Cooperation and Development). (2005). Is GDP a satisfactory measure of growth.

OECD (Organisation for Economic Co-operation and Development). (2016a). OECD Economic Surveys: Hungary May 2016, OECD Publishing, Paris.

OECD (Organisation for Economic Co-operation and Development). (2016b). Peer Learning Country Report: Netherlands, OECD Publishing, Paris.

Orłowski, W. (2011). Post-Accession economic development of Poland. Eastern Journal of European Studies, $2(2), 7-20$.

Paulina, F. (2017). Development of individual entrepreneurship in Poland under crisis conditions. Ovidius University Annals, Economic Sciences Series, 17(1), 484-490.

Raible, S. E. (2016). Entrepreneurship ecosystems: A comparison of the United States and Germany. Bosch Working Paper, No. XXXII. Robert Bosch Stiftung, Gerlingen. 
Rostow, W. W. (1959). The stages of economic growth. The Economic History Review, 12(1), 1-16.

Rusu, V. D. \& Roman, A. (2017). Entrepreneurial activity in the EU: An empirical evaluation of its determinants. Sustainability, 9(10), 1679-1695.

Sienkiewicz, M. W. (2014). Local economic development policy in Poland: Determinants and outcomes. Zbornik radova Ekonomskog fakulteta u Rijeci: časopis za ekonomsku teoriju i praksu, 32(2), 405-427.

Solow, R. M. (1956). A contribution to the theory of economic growth. The Quarterly Journal of Economics, 70(1), 65-94.

Stam, E. (2015). Entrepreneurial ecosystems and regional policy: A sympathetic critique. European Planning Studies, 23(9), 1759-1769.

Szira, Z. (2014). The situation of the SME Sector in Hungary. Management, Enterprise and Benchmarking - in the 21st century, 2014(1), 107-118.

Tamilmani, B. (2009). Rural women micro entrepreneurs: An empirical study on their social profile, business aspects and economic impact. Journal of Entrepreneurship Development, 6(2), 7-20.

Todaro, M. P. \& Smith, S. C. (2011). Economic Development. 11 $1^{\text {th }}$ ed. Essex: Pearson Education Limited.

Toma, S. G., Grigore, A. M. \& Marinescu, P. (2014). Economic development and entrepreneurship. Procedia, Economics and Finance, 8(2014), 436-443.

WEF (World Economic Forum). (2017). The inclusive growth and development report. World Economic Forum, Geneva.

Wennekers, S. \& Thurik, R. (1999). Linking entrepreneurship and economic growth. Small Business Economics, 13(1), 27-55.

Wennekers, S., Van Stel, A., Carree, M. \& Thurik, R. (2010). The relationship between entrepreneurship and economic development: Is it U-Shaped? Foundations and Trends in Entrepreneurship, 6(3), 167-237.

World Bank. (2018). World development indicators. [Online], World Bank Group. 